
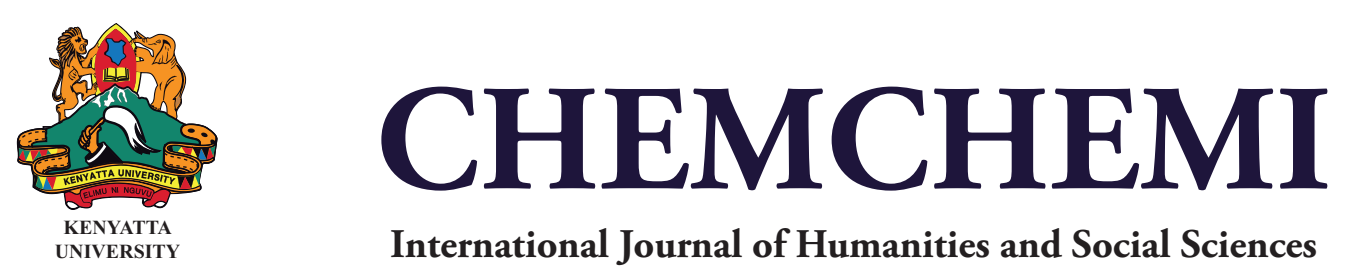

International Journal of Humanities and Social Sciences

Volume 11 Number 1, 2020

ISSN 2663-0826

ORIGINAL RESEARCH ARTICLE

DOI10.33886/cijhs.v11:1.137

OPEN ACCESS

\title{
THE EFFECTS OF COLONIALISM ON INDIGENOUS CONFLICT RESOLUTION SYSTEMS AMONG POKOT AND TURKANA COMMUNITIES
}

\author{
Mary Wahome and Daniel Ng'ang'a
}

\begin{abstract}
Colonialism impacted local cultures far beyond their infrastructure, government and geography. In addition to eroding indigenous power structures, the structural violence inflicted during colonialism left native populations with lasting self-doubt and rejection of traditional practices. Among these rejected traditions were informal processes and mechanisms of resolving conflicts. Conflict resolution methods in different cultures often vary greatly in underlying values and perceptions. Western judicial systems reflect individualistic, high uncertaintyavoidant, low-context tendencies, while indigenous conflict-resolution methods reflect collectivistic, minimal uncertainty-avoidant and high-context tendencies. Research into the current state of formal courts and informal justice forums in Pokot and Turkana Counties provides case study-based evidence arguing that the transition from restorative justice (Lapai) offered by indigenous justice mechanisms to retributive justice catalyzed by colonialism has effectively weakened both the Turkana and Pokot systems of justice. Due to impacted value systems, neither the restorative, social harmony focus of traditional processes, nor the retributive, compensatory justice focus of the formal judicial system make the available forums wholly appropriate or adequate resources. This has left the two communities torn between two distinct choices - the western and indigenous approaches to conflict management. The main objective of this research was to investigate the effects of colonialism on indigenous conflict management in Pokot and Turkana counties. These were both positive and negative effects. To achieve this objective the overarching question was; "how did colonialism affect the indigenous approaches to conflict management in Pokot and Turkana counties? The study was designed to apply qualitative research methods. Both structured and semi-structured interviews were conducted along the Turkana-Pokot borders. This paper proposes a hybrid model in conflict management, not only for the Pokot and Turkana pastoral communities, but also to other pastoral communities with similar set-ups.
\end{abstract}

Key words: Lapai, formal, informal, indigenous, Kokwo, tree of men, restorative, punitive, retributive-Justice, communities, Pokot and Turkana

\section{Introduction}

According to Mamdani (1996), colonialism left a lasting impact on the cultural structures of the colonized. Mamdani's expertise on the subject gives weight to his theory of decentralized despotism, a crucial concept of the political structure used by colonists to wield racialized power. This is manifested in Kenyan communities, where there was adaptation of western conflict management approaches at the expense of indigenous conflict management structures.

The state's exploitation of indigenous vulnerability calls upon Tatum's theory of internal colonialism that sheds light on ways in which colonialism impacted identity in the long- term (Tatum, 2002). Internal colonialism as 
Tatum reveals is one of the main factors contributing to the depreciated state of indigenous justice systems in Pokot and Turkana counties in Kenya today.

\section{Pre-colonial Pokot and Turkana Systems}

Prior to the colonial period, livestock transactions served to maintain social interactions that cut across ethnic boundaries and linked neighbouring ethnic groups. That was grown out of mutual economic interests between groups that lived near each other. According to Mkutu (2003), the Turkana established dependent relationships with the Pokot and Karamoja, which allowed them access to dry season grazing across the border with Uganda. $\mathrm{He}$ adds that such relationships were very beneficial in securing individual survival in the event of disasters such as raids, drought, and diseases. However, poverty occurred whenever this system of reciprocity broke down. The Pokots and Turkanas with other Pastoral communities in the region such as Dassenech or Merile, and Toposa would freely graze their animals in their neighbours' territory, guided by the indigenous structures. The elders had to give permission to the other community to graze in their territory. The same arrangement is still in place today, but has been disrupted by fixed borders that were established by the colonialists (Muwonge, 2009 and Bevan, 2007). Central to this arrangement were the indigenous institutions that were mandated to resolve any disputes arising due to non-compliance to the established rules; payment of fines or Lapai was the norm for failure to keep the rules especially when death occurred as a result caused by the conflict.

\section{Pokot and Turkana Systems During the Colonial Period}

The indigenous structures and institutions were affected during the colonial era mainly with the fixing of the border that separated communities across newly created countries as well as within the same countries for British self-interest of divide and rule. For example, the British colonial government in Kenya adopted policies that contributed to the economic and political marginalization of pastoral communities during colonial rule. The colonial governments favoured the establishment of agricultural white settlers and a plantation economy at the expense of peasant production. Colonial officials regarded pastoralism as a primitive mode of production and efforts were made to discourage it. Mkutu, (2003:13) and Leff, (2009:192) Postulates that, the creation of fixed ethnic borders did not only limit free access to grazing land and water, but also increased territorial ethnic land area, and social conflict among the pastoral Africans. This would not only affect the movement of the pastoralists but also created the notion of difference among the Pokot, Turkana and other pastoralists. Such difference would today complicate the use of Lapai/fine in indigenous conflict management in intercommunity conflict, which was not the case before colonialism. With the modern formal education, which is a product of western influence some community opinion leaders from both sides would prefer court process rather than indigenous approach in conflict resolution.

\section{Post-colonial Pokot and Turkana Counties}

It is arguable that the state of marginalization among the pastoralists in the northern Kenya did not end with independence. As Pavenelo argues, 'policies pursued by post-colonial governments failed to reduce the exclusion of pastoralists from mainstream national development'. There has been a tendency to neglect the needs of pastoralists and even to envisage the gradual eradication of pastoralism. More attention has been paid to the interests of agriculture and urban dwellers (Pavanello, 2013:5). In addition, the post-colonial period has seen a further weakening of traditional governance institutions in pastoral community areas in Pokot and

Turkana counties. This is partly due to the failure of the Kenyan and Ugandan governments to realize the role of the traditional institutions in management at the community level. (Ngeiywa and Benson, 2008:27). 
At the Pokot-Turkana border the erosion of traditional governance institutions has weakened the ability of community elders to exercise control over young men especially in cattle raid. While "eldership" was a merit prior to colonization, today it can be attained by wealth, and youth are often well positioned to attain wealth if they can gain access to guns. Elders now have to 'negotiate' with such youth in a way that has not been the case in the past. While in article 159 of the Kenyan constitution 2010 mentions of the alternative justice systems and the role of elders in conflict management little has been done to empower them. At the same time, official administrative governance structures since post-colonial period have usually been unrepresentative. Kendagor claims that, collaboration and co-ordination between the governments and their Border societies are relatively rare unless a raid takes place. The authorities have undermined traditional structures without 'modern' alternatives being established to replace them (Kendagor, 2005:7).

\section{Findings and Discussions}

Indigenous conflict resolution systems have roots as old as the tribes of people who crafted them. The outside influence of trade, missions and inter-group warfare is palpable, yet for the most part conflict resolution forums remained unchanged throughout centuries of heterogeneous cultural interaction. As long as the values of society held firm, definitions of conflict and sanctioned methods of resolution served societies well without change. Colonialism, with its new governing body and legal structure, imposed differences that went deeper than structural change. The very foundations of indigenous society were shaken to the core during colonization. Opposing values were present in all parts of colonial society, and the native culture reeled from the confrontation.

Nowhere is the impact of the cultural collision between colonists and colonized more evident than in the deterioration of indigenous conflict resolution systems. In Pokot and Turkana counties, traditional councils the kokwo and ekuko (tree of men) respectively, which had formerly fulfilled the responsibility of resolving conflicts were now weakened and people were torn between either choosing the indigenous or western approaches. The colonial government declaring the then west Pokot District a "closed district" worsened the situation because the colonial government perceived the community as hostile and primitive and heightened the need to change their cultural practices by imposing western rule of law. Recent assessments done in Sarmach and Kainuk indicated that most community members recognized the main function of the village council was to maintain peace (58\%), but also noted that the council did not treat everyone equally, mostly due to favoritism (while handling intra-conflicts) and tribalism (in inter-community conflicts) (see Appendices A \& B). A significant portion (39\%) of the youths themselves cited lack of faith in council process as the main reason that community members would take a dispute to an alternate forum (see Appendix C). One reformed warrior stated that he thought people wouldn't take a dispute to the village council if they thought the council wouldn't handle the matter well.

A common regret shared by some young elites was the lack of community respect for the council. A female worker with an NGO in the region voiced support for training so that "the council could get respect. This will help reclaim the lost glory". She also argued that the western approaches alone are not sufficient in community dispute management referring to the Kenyan constitution, 2010, which empowers the indigenous conflict resolution mechanisms as an alternative.

How did the traditional council system stray so far from the steadfastness it must have had to remain effective 
for many generations prior to the onset of colonialism? In response to this question, some members of the formal justice system in Kapenguria implied that the reason people came to the court to solve disputes was that they would fail to receive 'justice' at the hands of the local council. A woman peacemaker from Kacheliba while explaining a case where the local chief and some elders had been compromised by the perpetrator of a domestic violence said, "Justice is more lasting, more credible in court" (peace ambassadors interview 18 October 2015). Another peacemaker concurred, "Generally we all know why courts exist. It is for justice. Even the common man knows that. That is where they can seek justice especially when the elders have failed!" (Peace ambassadors interview 18 October 2015). A third woman peacemaker, when questioned about alternative justice forums, observed that "To an extent, some are effective. Some are not effective. The traditional council is not a court. It does not have coercive power and it cannot command people to attend. People have to attend based on sheer will. Neither can it handle conflicts of huge magnitude."

The traditional council's decisions are not binding, and they cannot be enforced. The councils have no army or police to enforce their decisions. This is why Hybrid model is important (Finn Church Aid NGO officer interview, 14 June, 2015). The suggestion that voluntary attendance is a weakness exemplifies how colonialism reframed ideas of power and authenticity. Before colonialism, the only option for conflict resolution was a traditional council, an institution that was too established and respected to be voluntary. The imposition of formal justice systems rebranded council of elders and reconciliation ceremonies as 'informal' and far less authentic and recognized than the Western alternative. In contrast, formal justice systems could issue court orders or summons; though in practice these are hardly more effective than the council calling a participant to attend a mediation meeting. Due to its formal nature, the Western system is assumed to wield more power. Thus appearing superior compared to indigenous justice system.

Many of the members of the formal justice system referred to the traditional councils as "quasi-judicial forums." The title alludes to the moral and legal inferiority that those in the formal justice system equate with the indigenous one. Even the concept of 'justice' itself is one over, which the Western system, and those certified in its practice, retain a monopoly. In addition to the usual condemnation, an elite working for an NGO in the region expressed anger and frustration at the inadequacy and dishonesty of the indigenous courts (Kokwo and ekuko respectively) he argued; the council of elders are not a court or anything. They have no jurisdiction over anything. Their job is just a civic duty, like peacekeeping, and best as part of "Nyumba kumi" initiative. Unfortunately we have some elders who are "politician's puppets" and water down the true role of elders. And they are so corrupt! How many times have you seen some elders crowning a politician as a community kingpin and a few days later another group of elders comes up and disowns the others and calls them fake"(Local chief interview, 16 July 2015).

In Pokot and Turkana, the traditional system of kokwopoyi and ekuko in which the community would witness and support the restorative justice and reconciliation of a fractured relationship is still in use today. Though in most cases, the performance of these reconciliation council rituals holds very little of the same meaning that it did previously before the colonization. The lack of meaning is apparent in the reality that Kokwo and ekuko sittings are today incapable of reconciling inter-ethnic relationships; specifically it has been a challenge to use lapai in the inter-conflict between Pokot and Turkana communities, something that was common before colonialism. In the event where it was attempted people participated in them but their attitudes and perspectives remained unaffected by the process. The restoration of relationships used to be the main purpose of these Kokwo-Poyi sittings, and the reason for their conception. Now that they fail to produce the intended result, the 
lapai is merely a superficial charade of a once-meaningful event in lieu of inter-ethnic conflict. However, it is worth noting that the success of these lapai in intra-conflicts in the two communities cannot be understated.

Among the Pokot the cursing ceremonies are a necessary part of customary conflict resolution due to their longevity and effectiveness. Africans in general believed in the existence of curses but in a more unique way Pokot and Turkana communities invoke curses in a ritual (burying the hatchet) as the last resort in resolving conflicts. These rituals have been used in the past conflicts to seal the peace agreements among other pastoralist communities. This is not unique among pastoralists as it is a common tradition in other pastoralist counties split in myriad ways across geographic, linguistic and tribal lines. The fact is that these ceremonies speak to these communities' original value and efficacy prior to colonial period.

The Turkana and Pokot regard the burying hatchet ceremony as a non-negotiable step in the process of managing and resolving conflict. They act as a seal and a culmination of the indigenous peace processes and agreement. In addition the interviewees claimed that indigenous rituals marked closure of conflicts among many African communities. For even the few issues that were brought to the police, society would require a custom ceremony to ritualistically acknowledge the resolution of the conflict. In a part of the world that was once rife with violent tribal clashes, people revered muиma - cursing ceremonies, and universally regarded them as the tool to keep communities healthy and just.

At the present day communities in Pokot and Turkana still regularly use KokwoPoyi sittings for resolving conflict at the community level, often without success. Reasons cited include but not limited to "lack of seriousness and trust that was invested in the council of elders". The purpose of paying lapai is to restore the damaged relationship between disputing parties through public offerings of compensation on both sides. Lapai gives the impression of protecting social harmony upon which tight-knit, collectivistic societies such as those in Pokot and Turkana survive. Yet, these sittings fail to produce the same outcome as originally intended. No longer satisfied with a restorative mechanism, disputants do not attend kokwo sittings with intention to forgive or to prioritize the relationship. Participants in Kokwo sittings reported that it has turned to merely a formality and a shadow of the original sittings where the elders were strictly referred as the 'coffers of truth' and their word was final. The bottom line being there is an alternative of going to court, which was not there before colonialism. Lapai declared by the Kokwo was only aimed at material restoration since the parties involved in case of killing a kinsman during the conflict were banished from the community. This was meant to instill fear among those who would be perpetrators and enhance social harmony (Interview with Lengosiwa, July 2015).

The informal conflict resolution systems of traditional councils grew from a local, collective concept of justice derived of what society thought was fair and equal; these notions had obviously been greatly impacted by both colonialism itself and the example set by the Western justice systems. Former standards stemming from indigenous society had relied on collective meaning and collective priorities to form a conflict resolution process that met the need for restoring social balance.

According to Zartman (2000), Conflict management in these cases can take advantage of referents in values, authority and community to anchor its efforts; it is essentially calling the offender to order, preserving the community and hierarchy and restoring the harmony of society. This context is particularly important. The ideas of equality and fairness had changed as a consequence of the imposition and standardization of Western norms, in which property was paramount, violations, required restitution and criminals were bad members of society 
who must be jailed and excluded, for the good of society. The prior process, using a traditional arbitrator who relied on knowledge of a past relationship, context and the collective belief in the importance of a continued relationship in order to reconcile parties lost the confidence of the locals in the community. The restorative penalties favored by indigenous justice processes seemed inferior and not aligned to the newly discovered standards of the local population. Perhaps the issue is not that the traditional system became ineffective, but that the evolved cultural needs are not truly understood. In his book, Culture and Conflict Resolution, Avruch (1998) explores the difference between conflict resolution and other forms of conflict management. Conflict resolution is so called because of its aim "somehow to get to the root causes of a conflict and not merely treat its episodic or symptomatic manifestation" (Avruch, 1998: 26). The indigenous system at one time aimed to directly address the root causes of conflict the broken relationship in a community. Outside influence and natural evolution have changed indigenous cultural values to the point that the process does not hold the broken relationship to be the root cause of the conflict.

Dissatisfaction with the indigenous forms of conflict resolution is a form of grievance with the structures of governance and community. Conflicts between disputants lead to conflict with the resolution process. Negotiation expert William Zartman refers to this situation as "neither authority-neutral nor authorityreinforcing but authority-destroying," while noting that these types of conflicts are the most difficult to handle. (Zartman, 2000: 9) The de-legitimization of tribal authorities and customs, a secondary objective of the colonists, remains a consistent problem.

In the new system due process focused only on the act of someone being wronged, and the power of the state to 'correct' that wrong, and as a result restorative penalties and processes were simply not what people wanted. Compensation used to be rehabilitative as well as punitive; the party found guilty in Pokot and Turkana communities was required to pay the lapai fine of goats to the complainant. This process enabled the dishonored to rise to an honorable status. The public nature of the apology and fining also provided a strong social influence to follow through on one's promise to forgive (Abu-Nimer, 1996). Yet the rehabilitative focus of these penalties is no longer one that seems to satisfy local communities. After colonial courts taught a new framework through which to see the problem, one is right, the other must pay the old compensatory system became inapplicable to a great extend. Framed around the subject of peace-building processes, Mac Ginty (2008) argues that instead of reciprocation and sustainable resource sharing, there was the imposition of Western models of peace and peace-making, including surrender and re-grant, formal written peace treaties and the violent suppression of indigenous groups and appropriation of their resources. Indigenous social structures and inter-group relations were often eroded over a long period through the introduction of firearms, missionaries and money trading. Thus weakened, indigenous groups' customary norms of peace-making no longer retained their power (Mac Ginty, 2008: 153).

Following this loss of power, traditional peace-making or conflict resolution systems exist only as a souvenir of what they once were. Not only have the concepts of justice, fairness, and resolution changed, the local definition of a conflict has changed. The pattern of social reactions to conflict situations is not uniform, and neither are the connotations that people and societies attach to denotative meanings of conflict (Kruglanski, Bar-Tal and Klar, 1993). 


\section{Conflict and Identity}

It can, arguably, be that cultural identity is a major cause of conflict. Identity crisis or crash has in the past led to protracted conflict in different communities. Cultural identity was but one of the many basic needs deprived in the structural violence of colonialism. The loss of a former collective identity was only one of many changes in formerly collective meaning and social understanding. One such collective meaning was the group definition of conflict; what constitutes errant behavior is culturally defined and reflects cultural consensus. Native understanding of what defined conflict, and what defined proper resolution of conflict, was a key indicator of the change in cultural standards.

An example of the shifting paradigm of conflict is the increase in border disputes, a serious problem along the Pokot - Turkana border. Before colonialism, there were few troubles over boundaries and there was nothing like personal land among the two communities. Colonialism brought with it the Western perception of ownership as an individual, unalienable right (Universal declaration of Human rights); the collectivistic nature of ownership was destroyed or weakened at behest of the colonialists divide and rule tactics of survival. Western ideas of ownership have influenced local landowners' need to aggressively defend or pursue their disputed property in courts of law. Land dispute cases are handled by a Western, position-based system, which results in a fixed outcome. Whether the land is divided or awarded only to one party, neither is satisfied with the distributive process, which divides the outcome and leaves the parties' identities without reconciliation. This is what some politicians are advocating for as a solution to the border conflict between the Turkana and Pokot - an indication of how colonial legacy has continued shaping and influencing People's thinking.

How a society defines problems reflects their self-understanding; responding to a stimulus with action or inaction indicates whether the source of the problem is considered internal or external (Criss and Johnson, 1993). Definitions of conflict or crime are subjective. There are only acts that are given certain meaning within social frameworks, and the meaning attributed to these acts is suggestive of certain features of a society (Gabiddon, 2010). Dispute resolution in any culture reflects values, psychological imperatives, history, and economic, political, and social organization (Jandt and Pedersen, 1996). Social and personal identity is wound up in perceptions of conflict, and thus identity is a vital part of the resolution of conflicts.

Human needs, including identity, are a basic necessity for survival and positive peace (Galtung, 1969). Edward Azar's theory of how the deprivation of human needs is a direct factor in protracted social conflict includes social identity (Azar, 1986). Azar (1986: 29-30) observes that "It is the denial of human needs, of which ethnic identity is merely one, that finally emerges as the source of conflict". Colonialism's indifference to ethnic identity, evident through the many and diverse ways in which this identity was minimized, is no small part of the environment of negative peace.

Identity is central to conflict, and reconciliation must address identity, transforming if necessary the aspects of identity that are linked to the conflict (Schirch, 2001). In high-context, collectivistic cultures such as Pokot and Turkana with relationships and social bonds, in effect, the connections between people are what define identity. Especially in indigenous societies, conflict resolution is linked to identity formation and maintenance (Mac Ginty, 2008). The transformation of identity out of conflict would require renewing or reinforcing social connections between disputants. Turkana and Pokot communities prioritized the Kokwo-poyi sittings, which determined the compensation of the aggrieved parties. Before colonialism these indigenous councils kept these conflict resolution systems functioning effectively. 
While conflict resolution involves an active focusing on the conflict interpretation in ways that may lead to a reassessment of its validity, conflict resolution may occur when the conflict schemer is put out of the focus of attention and moved into relative obscurity. It follows that a conflict interpretation left inactive for long periods of time might become relatively inaccessible and thus ceases to exert any appreciable influence on judgments and behavior (Kruglanski, Bar-Tal and Klar, 1993: 53).

Inactivity of the prior interpretation of conflict and resolution made the traditional conflict resolution system on which it was based ineffective. High-context cultures had formerly seen conflict as part of the ongoing holistic relationship of all society. In the new framework after colonialism, conflict became instead something that was inherently negative and needed to be removed from society while being handled only by those deemed worthy of the task. This "elitising" conflict management by the western approaches only served to weaken the existing indigenous mechanisms. Conflict resolution became results-orientated rather than process-focused, and the concept of social harmony was no longer a concern now that reconciliation ceased to be a central goal.

The new Western judicial system further added to the problem of human needs deprivation. Lacking ownership over an effective conflict resolution process left the indigenous struggling to meet their basic needs. Not only did the Western legal system fail to meet these needs, the natives' own original forums had become ineffective. The tools once employed to meet native needs were now futile due to the change in cultural perception. In a way the colonialists had succeeded in dividing the community. Without their own definition of conflict, the locals had lost their definition of themselves and were forced to search for a new identity within the new western framework. Along with this new framework came a host of problems with traditional and modern justice systems.

\section{Conclusion}

As presented in this research's arguments and claims it can be concluded that formal justice system weakened the indigenous conflict management mechanisms to a great extent. Social harmony among the Turkana and Pokot communities was based on the long-standing indigenous resolution systems built upon restorative justice. However, the effects of colonialism cannot be underscored as highlighted in the paper. Colonialism superimposed a system of justice premised on completely different social values. While the indigenous justice system mainly ended in a win- win situation the western approaches and processes led to a win-lose situation. The collision of these two opposing cultural perspectives on conflict resolution left post-colonial societies with functioning but inadequate options.

Although Africa has self determination colonialism is ever present, lingering in today's many conflict resolution forums in post-independent states. Whether the indigenous systems of justice now condemned as biased; ritual reconciliation ceremonies now failing to resolve deeply rooted conflicts; or Western institutions of justice unable to serve the population adequately, local communities are without a single effective, reliable means to conflict management. The research points out clearly that there is no one 'fit-all' conflict situation approaches and 'cut and paste' approaches are bound to fail. Western approaches should not be imposed on every situation but rather they should be tailor-made to take to account the local needs, as each conflict is unique.

Interviews in the research for this work show that concepts of justice and people's desire for fair and fitting dispute resolution have altered drastically since colonialism. The change in perceptions of conflict resolution 
options meant that the basic human need of means to a peaceful society was unmet. The understanding of notions such as unbiased justice, fair compensation and the purpose of penalties have all shifted in response to Western framing. The reconfiguration of native identity and the corresponding cultural values has caused successful conflict resolution to remain elusive in post-independent states. The need for restorative justice makes Western courts unfathomable, while the new ideas of justice based on the retributive system of the colonists render traditional forums substandard.

To reduce all the comments and perceptions in this exploratory research to a single point, there is a basic similarity between native dissatisfaction with informal and formal justice systems alike. The current indigenous systems seem insufficient, while the formal justice system lacks indigenous values. Neither system fits perfectly because neither one is a product of cultural expression and ownership. As such, neither fully meets basic human needs, without which internal and systemic conflict is standing by. It is arguable that the lack of cultural ownership is the main factor influencing informal and formal conflict resolution systems' inadequacy. How could either of these systems one from an untouched world, one a foreign import fit changing values? Any conflict resolution system that attempts to successfully serve a population must originate from the people themselves, according to their specific values and beliefs. For example the conflict between the Turkana and Pokots of North rift Kenya can well be addressed basing on their existing cultural values, however these too have been infiltrated by western values that are still alien to indigenous people.

The ultimate goal for successful conflict resolution post-independence is a system by which all people are satisfied. With this objective in mind, it is simple to identify the weaknesses in the current conflict resolution options. Formal systems that bear the mark of colonial imposition fail to recognize and respect the culture of the indigenous.

Based on these arguments the study recommends a hybrid approach of both western and indigenous systems. For Pokot and Turkana, none of the currently established systems are wholly accurate for conflict resolution. Communities should be allowed to identify and correct the inefficiencies and inadequacies in the conflict resolution systems designed to serve their needs. These systems will have to be reformed or a new system created if there is to be social order, harmony, and lasting peace.

\section{References}

Abu-Nimer, M. (1996). Conflict Resolution Approaches: Western and Middle Eastern Lessons and Possibilities. American Journal of Economics and Sociology, 55 (1), 35-52.

Aghelmo, A.T. \& Ibhasebhor, S. (2006). Colonialism as a Source of Boundary Dispute and Conflict among African States: The World Court Judgment on the Bakassi Peninsular and its Implications for Nigeria. The Journal of Social Science, 13(3), 177-181.

Arthur, J. \& Marenin, O. (1996). British Colonization and the Political Development of the Police in Ghana, West Africa. In C. Fields \& R. Moore, Jr (Ed.), Comparative Criminal Justice: Traditional and Nontraditional Systems of Law and Control (pp. 163-180). Illinois: Waveland Press, Inc.

Assefa, H. (1993). Peace and Reconciliation as a Paradigm: A Philosophy of Peace and Its Implications on Conflict, Governance, and Economic Growth in Africa. Kenya: Nairobi Peace Initiative Monograph Series.

Avruch, K. (1998). Culture and Conflict Resolution.Washington, DC: The United States Institute of Peace Press.

Azar, E. (1986). Protracted International Conflicts: Ten Propositions.

Burton (Ed.), International Conflict Resolution: Theory and Practice (pp.28-39). Sussex: Wheatsheaf Books. 
Burgos-Debray, E., Ed. (1983).Me LlamoRigobertaMenchu Y Asi Me Nacio La Concienca. Barcelona: Editorial Argos Vergara.

Chanock, M. (2000) 'Culture' and human rights: orientalising, Occidentalizing, and authenticity. In M. Mamdani (Ed.), Beyond Rights Talk and Culture Talk: Comparative Essays on the Politics of Rights and Culture (pp. 15-36). New York, NY: St. Martin's Press.

Chinua Achebe (1958) Things fall apart. William Heinemann Ltd.

Churchill, W. (2003). Perversions of Justice: Indigenous Peoples and Anglo-American Law. San Francisco: City Lights.

Criss, J. \& Johnson, P. (1993). Community Psychology Applied to Peace Studies. In K. Larsen (Ed.), Conflict and Social Psychology (pp. 133-143). Olso: International Peace Research Institute.

Estrada-Hollenbeck, M. (2001). The Attainment of Justice through Restoration, not Litigation: The Subjective Road to Reconciliation In M. Abu-Nimer (Ed.), Reconciliation, Justice, and Coexistence: Theory and Practice (pp. 65-86). Maryland: Lexington Books.

Fisher, R. (1993). Towards a Social-Psychological Model of Intergroup Conflict. In K. Larsen (Ed.), Conflict and Social Psychology (pp. 109-122). Olso: International Peace Research Institute.

Galtung, J. (1969). Violence, Peace, and Peace Research. Journal of Peace Research, 6 (3), 167-191.

Gabiddon, S. (2010). Race, Ethnicity, Crime, and Justice: An International Dilemma. Los Angeles: Sage Publications, Inc.

Gopin, M. (2002). The Use of the Word and Its Limits: A Critical Evaluation of Religious Dialogue as Peacemaking. In D. Smock (Ed.), Interfaith Dialogue and Peacebuilding (pp. 33-46). Washington, DC: United States Institute of Peace.

Hall, E. (1976). Beyond Culture.New York: Anchor Books. Hosftede, G. (1997). Cultures and Organizations: Software of the Mind. New York: McGraw-Hill.

Huffer, E. \&Molisa, G. (1999). Governance in Vanuatu. Pacific Economic Bulletin, 14(1), 101-112.

Jandt, F. \& Pedersen, P. (1996a). Culturally Contextual Models for Creative Conflict Management. In F. Jandt \& Pedersen P. (Ed.). Constructive Conflict Management: Asia-Pacific Cases (pp. 3-26). California: Sage Publications, Inc.

Jandt, F. \& Pedersen, P. (1996b). The Cultural Context of Mediation and Constructive Conflict Management. In F. Jandt \& Pedersen P. (Ed.). Constructive Conflict Management: Asia-Pacific Cases (pp. 249-275). California: Sage Publications, Inc.

Kendagor R. D. (2005). Rethinking pastoralism and African Development: A case study of the horn of the Horn of Africa. Egerton University.

Kriesberg, L. (2001). The Changing Forms of Coexistence. In M. Abu-Nimer (Ed.), Reconciliation, Justice, and Coexistence: Theory and Practice (pp. 47-64). Maryland: Lexington Books.

Kruglanski, A., Bar-Tal, D. \& Klar, Y. (1993). A Social Cognitive Theory of Conflict. In K. Larsen (Ed.), Conflict and Social Psychology (pp. 45-56). Olso: International Peace Research Institute.

Mac Ginty, R. (2008). Indigenous Peace-Making Versus the Liberal Peace. Journal of the Nordic International Studies Association, 43(2), 139-163.

Mamdani, M. (1996). Citizen and Subject: Contemporary Africa and the Legacy of Late Colonialism. Princeton, NJ: Princeton University Press.

Mani, R. (2000). The Rule of Law or the Rule of Might? Restoring Legal Justice in the Aftermath of Conflict. In M. Pugh (Ed.), Regeneration of War-Torn Societies (pp. 90-111). Great Britain: Macmillan Press, Ltd.

Menon, N. (2000). State, community, and the debate on the uniform civil code in India. In M. Mamdani (Ed.), Beyond Rights Talk and Culture Talk: Comparative Essays on the Politics of Rights and Culture (pp. 75-95). New York, NY: St. Martin's Press.

Montville, J. (2001). Justice and the Burdens of History. In M. Abu-Nimer (Ed.), Reconciliation, Justice, and Coexistence: Theory and Practice (pp. 129-144). Maryland: Lexington Books.

Moore, M. (1993). Mirroring and Misperceptions: "Where ignorant armies clash by night;" A review of misperceptions and mirroring in intergroup relations. In K. Larsen, (Ed.), Conflict and Social Psychology 
(pp. 71-80). Olso: International Peace Research Institute.

Moosa, E. (2000). Tensions in legal and religious values in the 1996 South African Constitution. In M. Mamdani (Ed.), Beyond Rights Talk and Culture Talk: Comparative Essays on the Politics of Rights and Culture (pp. 121-135). New York, NY: St. Martin's Press.

Mkutu, (2003). Pastoral Conflict and Small Arms: The Kenya- Uganda Border Region Safer world, London. Available at: http ://www. Safer world.org. uk/images/

Pub. docs/Pastoral conflict. Pdf.

Nader, L. (2002). The Life of the Law: Anthropological Projects. Berkeley: University of California Press.

Nader, L \& Todd, H, Jr., Eds. (1978). The Disputing Process - Law in Ten Societies. New York: Columbia University Press.

Nhalpo, T. (2000). The African customary law of marriage and the human rights conundrum. In M. Mamdani (Ed.), Beyond Rights Talk and Culture Talk: Comparative Essays on the Politics of Rights and Culture (pp. 136-148). New York, NY: St. Martin's Press.

Pavanello, S. and Scott-Villiers, P. (2013). Conflict resolution and peace building in the drylands in the Greater Horn of Africa. Brief prepared by a Technical Consortium hosted by CGIAR in partnership with the FAO Investment Centre. Technical Consortium Brief 6. Nairobi: International Livestock Research Institute.

Penal Reform International. (2000). Access to justice in sub-Saharan Africa: the role of traditional and informal justice systems. United Kingdom: Astron Printers, Ltd.

Shivji, I. G. (2000). Contradictory perspectives on rights and justice in the context of land tenure reform in Tanzania. In M. Mamdani (Ed.), Beyond Rights Talk and Culture Talk: Comparative Essays on the Politics of Rights and Culture (pp. 37-60). New York, NY: St. Martin's Press.

Smith, J. (1996). The Effects of Tribal Wars on Personal and Family Disputes in Papua New Guinea. In F. Jandt. \& Pedersen P. (Ed.). Constructive Conflict Management: Asia-Pacific Cases (pp. 112-118). California: Sage Publications, Inc.

Tangiora, P. (1996). An Indigenous Perspective on One Aspect of Reconciliation. In F. Jandt \& P. Pedersen (Ed.), Constructive Conflict Management: Asia-Pacific Cases (pp. 215-219). California: Sage Publications, Inc.

Tatum, B. (2002). The Colonial Model as a Theoretical Explanation of Crime and Delinquincy. In S. Gabiddon, H. Greene, \& V. Young, (Ed.), African American Classics in Criminology and Criminal Justice (pp. 307-322). California: Sage Publications, Inc.

Zartman, I. W., Ed. (2000). Traditional Cures for Modern Conflicts: African Conflict Medicine. Boulder, CO: Lynne Reinner Publishers, Inc. 